\title{
PENGARUH EKSTRAK BUAH NENAS (Ananas comosus l.merr) TERHADAP KUALITAS FISIK DAN ORGANOLEPTIK DAGING KUDA DENGAN LAMA PEREBUSAN YANG BERBEDA
}

\author{
Anita Mustika Ibrahim ${ }^{1}$, Harapin Hafid ${ }^{2}$ dan Rahim Aka ${ }^{2}$ \\ ${ }^{11}$ Alumnus Jurusan Peternakan Fakultas Peternakan UHO \\ ${ }^{2}$ Dosen Jurusan Peternakan Fakultas Peternakan UHO \\ e-mail : harapinhafid14@gmail.com
}

\begin{abstract}
ABSTRAK
. Tujuan penelitian ini adalah mengetahui pengaruh interaksi antara penambahan ekstrak buah nenas dengan lama perebusan yang berbeda terhadap kualitas fisik dan organoleptik daging kuda. Penelitian ini menggunakan Rancangan Acak Lengkap (RAL) dengan pola faktorial. Faktor pertama (A) adalah 30 menit lama perebusan (A1), 40 menit lama perebusan (A2) dan 50 menit lama perebusan (A3). Faktor kedua (B) adalah 0\% campuran eksrak nenas (B1), 5\% (B2) dan 10\% (B3). Masing-masing perlakuan diulang sebanyak tiga kali. Variabel yang diamati adalah kualitas fisik dan organoleptik. Hasil penelitian menunjukkan Interaksi antara penambahan ekstrak buah nenas dan waktu pemasakan tidak berpengaruh terhadap kualitas organoleptik (keempukan, tekstur, juiceness) dan kualitas fisik (susut masak, $\mathrm{pH}$ ) akan tetapi berpengaruh nyata terhadap rasa dan aroma daging kuda. Ekstrak buah nenas secara mandiri berpengaruh nyata terhadap kualitas fisik( susut masak) dan kualitas organoleptik (keempukan, rasa, tekstur, juiceness) daging kuda dan waktu lama perebusan secara mandiri, berpengaruh nyata terhadap keempukan, juiceness dan susut masak daging kuda.
\end{abstract}

Kata kunci : Nenas. Lama perebusan, Kualitas fisik, Kualitas organoleptik

\begin{abstract}
. The research was purposed to know the interaction effect of nenas extracts on physical quality and organoleptik of horsemeat with different brewing time. This experiment used factorial pola based on first factor (A) is time of cooking and divided into A1 (30 minutes cooking time). A2 (40 minutes cooking time), A3 (50 minutes cooking time). The second factor is the using of nenas extract (B) and divided into B1 (0\% extract). Each treatment was replied 3 times. Parameters measured were physical quality and organoleptic. The result of this experiment showed that there was an interaction between applying nenas extract and cooking time only on taste and aroma of horse meat. Nenas extract independently gave a significant effect on cooking loss, tenderness, texture and meat juiceness and cooking time independently gace a significant effect on tenderness, juiciness and cooking loss of horse meat.
\end{abstract}

Key words: Nenas, Cooking time, Physicall quality, Organoleptic quality

\section{PENDAHULUAN}

Kebutuhan protein hewani masyarakat dari tahun ketahun terus meningkat sebanding dengan meningkatnya jumlah penduduk dan kesadaran akan pentingnya kebutuhan gizi. Kebutuhan protein hewani itu yang dapat dipenuhi dengan mengkonsumsi komoditas hasil peternakan seperti daging, telur, dan susu (Hafid, 2008).

Daging sudah dikenal sebagai bahan pangan yang sempurna, karena kandungan gizi yang lengkap dan dibutuhkan oleh tubuh yaitu protein, energi, mineral dan vitamin. Disamping memiliki rasa dan aroma yang enak sehingga disukai oleh hampir semua orang (Hafid, et al. 2013). Salah satu jenis ternak yang perlu mendapatkan perhatian dan potensial untuk produksi daging adalah ternak kuda. Ternak kuda dapat menjadi alternatif penyedia daging sebagai salah satu sumber pangan yang mempunyai kandungan protein yang sangat tinggi. 
Akan tetapi daging yang berasal dari ternak kuda memiliki kealotan yang tinggi karena adanya jaringan ikat yang banyak, hal itu dikarenakan beberapa faktor selain umur, ternak kuda umumnya juga dijadikan sebagai pekerja. Menurut Lawrie (2003) dan Hafid (2011) keempukan daging dipengaruhi oleh protein jaringan ikat, semakin tua ternak jumlah jaringan ikat lebih banyak, sehingga meningkatkan kealotan daging. Besarnya ukurat serat otot pada daging kuda juga menyebabkan kealotan yang tinggi.

Solusi untuk mengempukan daging yaitu sebelum dilakukan pemanasan terlebih dahulu dilakukan proses perendaman dalam larutan enzim proteolitik. Selama proses perendaman daging terjadi hidrolisis protein serat otot, tenunan pengikat, dan terjadi perubahan-perubahan yang meliputi menipisnya serta hancurnya sarkolema, terlarutnya nucleus dari serabut otot dan jaringan ikat serta lepasnya keterikatan serabut otot sehingga dihasilkan jaringan lunak.

Salah satu enzim protease tersebut adalah bromelin yang berasal dari buah nenas, hampir dalam seluruh bagian tanaman terdapat enzim bromelin dengan jumlah yang berbeda-beda pada setiap bagiannya. Menurut Winarno et., al (1993) bromelin adalah enzim protease yang dapat menghidrolisis protein. tergantung oleh musim.

\section{MATERI DAN METODE}

\section{A. Waktu dan Tempat Penelitian}

Penelitian ini dilaksanakan di Laboratorium Kimia Forensik MIPA Universitas Halu Oleo Kendari, yang berlangsung selama 1 (satu) bulan yaitu bulan Agustus 2014.

\section{B. Materi Penelitian}

\section{Bahan Penelitian}

Bahan yang digunakan dalam penelitian ini adalah aquades, buah nenas dan daging kuda yang diperoleh dari RPH
(Rumah Potong Hewan) Kabupaten Jeneponto Sulawesi Selatan dan Buah Nanas yang dibeli di Pasar Buah Kota Kendari. Sampel daging yang digunakan sebagai bahan penelitian adalah daging pada bagian paha (leg).

\section{Peralatan Penelitian}

Alat yang digunakan untuk penyiapan sampel antara lain kulkas, timbangan digital biasa, timbangan analitik, thermometer, plastik PP (Poly, pisau, garpu, pemanas listrik (hot plate), nampan, piring, mangkok kecil, penangas air, tissue, water bath, batang pengaduk, tabung reaksi 100 $\mathrm{ml}$, blender, kertas isap, gelas piala $100 \mathrm{ml}$, baskom, Sendok, pH meter, Gelas, gunting, dan alat tulis menulis

\section{Prosedur Penelitian}

1. Cara Menyiapkan Daging Kuda

Daging kuda bagian paha (high) daging kuda yang telah diperoleh dari daerah Jeneponto Sulawesi Selatan di iris mengikuti arah serabut otot dalam bentuk kotak. masing-masing sampel daging kuda ditimbang seberat 100 gram persampel. kemudian sampel daging ditusuk-tusuk menggunakan garpu.

\section{Cara Menyiapkan Ekstrak Buah Nanas}

Buah nenas dipilih yang sudah matang namun tidak terlalu matang yang diperoleh dari pasar buah kota kendari. Pengupasan, kulit nanas dikupas dan mata kulitnya dibersihkan. Pencucian, nanas yang sudah dikupas dan dibuang mata kulitnya kemudian dicuci. Pemotongan, nenas dipotong kecil-kecil apabila akan diblender. Pemblenderan, nanas diblender sampai halus. Penyaringan, nanas yang sudah diblender mengeluarkan air. Air dan ampasnya dipisahkan dengan cara disaring.

\section{Proses Pengolesan dan Perebusan} daging kuda

Sampel daging penelitian yang telah ditusuk-tusuk dengan menggunakan garpu selanjutnya diolesi dengan ekstrak buah nenas sesuai dengan perlakuan yang 
diinginkan. kemudian sampel daging diinkubasi selama 30 menit pada suhu kamar. setelah lama waktu inkubasi selesai. sari buah nenas yang terdapat pada permukan sampel daging dibersihkan menggunakan tisue. lalu sampel dimasak sesuai perlakuan dimana lama perebusan pada suhu $60^{\circ} \mathrm{C}$. selanjutnya sampel didinginkan pada suhu $0-3^{0} \mathrm{C}$. setelah proses pendinginan selesai, maka dilanjutkan dengan dua metode pengujian, diantaranya uji fisik (susut masak dan $\mathrm{pH}$ ) dan uji organoleptik (Keempukan, Warna, Aroma, Cita Rasa (Flavor), Tekstur dan Sari minyak (juiciness).

\section{Rancangan Penelitian}

Penelitian ini dilakukan dengan menggunakan Rancangan Acak Lengkap (RAL) pola faktorial $3 \times 3$ dengan 3 ulangan sesuai dengan petunjuk Gasperz (1989)

Faktor A : Perlakuan berdasarkan persentase penambahan ekstrak buah nenas A1 = Tanpa sari buah nenas ( Kontrol)

A2 = Penggunaan Sari buah nenas sebanyak $5 \%$ dari berat daging

A3 = Penggunaan Sari buah nenas sebanyak $10 \%$ dari berat daging

Faktor B : Perlakuan berdasarkan lama perebusan

$\mathrm{B} 1$ = lama perebusan selama 30 menit

B2 = lama perebusan selama 40 menit;

B3 = lama perebusan selama 50 menit;

Penelitian ini akan di bagi dalam 2

tahap yaitu penelitian pendahuluan dan penelitian utama. Penelitian pendahulu dilakukan sebagai persiapan sekaligus uji coba peralatan, sehingga hal-hal yang dapat menyebabkan kesalahan penelitian dapat dihindarkan. Sedangkan penelitian utama dilakukan untuk melihat peranan dari pengaruh ekstra buah nenas terhadap kualitas daging kuda.

\section{E. Peubah Penelitian}

Peubah yang diamati dalam penelitian ini adalah :

\section{a. Susut Masak (Cooking Loss)}

Penetapan susut masak menggunakan metode menurut Soeparno (2009) dengan melihat berat yang hilang selama pemasakan. Sampel daging ditimbang 10 gram, dimasukkan dalam plastik PP, dan ditutup dengan rapat, kemudian direbus dalam penangas air dengan temperatur tertentu. Ambil daging dan serap permukaan daging menggunakan tissue (y). Susut masak adalah nilai dari selisih berat sebelum dimasak dan sesudah dimasak dibagi berat sample sebelum dimasak dikalikan 100 persen. Nilai susut masak (Cooking Loss) daging dihitung dengan rumus sebagai berikut :

$$
\begin{gathered}
\text { Susut masak }(\%)= \\
\frac{\text { berat awal sampel-berat akhir sampel }(g)}{\text { berat akhir sampel }} \\
100 \% \text {...(1) }
\end{gathered}
$$

b. $\mathbf{p H}$

Pengujian $\mathrm{pH}$ daging dilakukan dengan menggunakan metode Bouton et al. (1971) dalam Soeparno (2009) yaitu sampel daging seberat 10 gram dihaluskan kemudian dicampur dengan $10 \mathrm{ml}$ aquadest kemudian diaduk hingga homogen. Elektroda gelas pada $\mathrm{pH}$ meter dibersihkan dengan aquadest dan dimasukkan buffer $\mathrm{pH}$ 7 untuk disesuaikan pH-nya. Setiap larutan diukur pH-nya sebanyak tiga kali dan hasilnya direrata sebagai nilai $\mathrm{pH}$ daging.

\section{c. Uji Organoleptik}

Uji Organoleptik dengan hedonic test mengacu pada (Hafid dan Syam, 2007; 2009) yang meliputi warna (color), aroma, tekstur dan keempukan (tenderness), rasa (taste).

\section{F. Analisis Data}

Data yang diperoleh diolah dengan menggunakan rancangan dasar, rancangan Acak Lengkap (RAL) faktorial. Apabila hasil analisis sidik ragam perlakuan berpengaruh nyata maka dilanjutkan dengan uji BNT (Hanafiah, 2004). 
HASIL DAN PEMBAHASAN

\section{A. Kualitas Fisik Daging Kuda}

1. Susut Masak

Tabel 3. Rataan Nilai Susut Masak Daging Kuda Berdasarkan Penggaruh Ekstrak Buah Nenas (Ananas comosus l.merr) dengan Lama Perebusan yang berbeda.

\begin{tabular}{ccccc}
\hline faktor A & \multicolumn{3}{c}{ Faktor B } & Rataan \\
(Persentase penambahan & \multicolumn{3}{c}{ (Lama Perebusan yang Berbeda) } & \\
\cline { 2 - 4 } ekstrak sari buah nenas) & B1 & B2 & B3 & \\
\hline A1 & $27,39 \pm 0,82$ & $34,73 \pm 1,21$ & $35,72 \pm 5,07$ & $32,61^{\mathrm{a}} \pm 13,66$ \\
A2 & $33,02 \pm 0,41$ & $37,80 \pm 4,62$ & $38,65 \pm 7,33$ & $36,49^{\mathrm{a}} \pm 9,11$ \\
A3 & $52,81 \pm 2,63$ & $52,97 \pm 5,68$ & $62,24 \pm 5,16$ & $56,01^{\mathrm{b}} \pm 16,21$ \\
\hline Rataan & $37,74^{\mathrm{a}} \pm 40,05$ & $41,84^{\mathrm{ab}} \pm 29,29$ & $45,54^{\mathrm{b}} \pm 43,65$ &
\end{tabular}

- $\quad$ Ket. Superskrip yang berbeda pada baris dan kolom yang sama menunjukkan berbedaan yang nyata $(p<0,05)$

Interaksi antara faktor $\mathrm{A}$ dan $\mathrm{B}$ tidak menunjukkan pengaruh nyata $(p>0,05)$ terhadap nilai keempukan daging. Menurut Fisher (2009) faktor yang sangat berpengaruh terhadap kecepatan hidrolisis yaitu konsentrasi enzim yang ditambahkan, waktu hidrolisis (inkubasi), dan suhu.

Hasil uji sidik ragam pada faktor A dan faktor B secara tunggal berpengaruh sangat nyata $(p<0,01)$. Hasil penelitian ini menunjukkan bahwa dengan meningkatnya konsentrasi ekstrak buah nenas terjadi penurunan nilai daya tusuk daging. nilai daya tusuk daging menurun mengidikasikan terjadinya peningkatan keempukan daging Menurut Soeparno (2009) nilai daya tusuk daging semakin kecil daging akan lebih empuk.

Hasil penelitian sesuai dengan penelitian Murtini dan Qomarudin (2003) perendaman daging pada larutan enzim protease tanaman biduri dapat meningkatkan keempukan. Enzim-enzim pada tanaman protease untuk meningkatkan keempukan daging sudah banyak digunakan salah satunya buah nanas. Menurut Lee et al., (1994) enzim protease berfungsi mengempukkan daging, karena protein pada jaringan ikat dan fragmentasi miofibril dengan degradasi pada filamenfilamen akan terhidrolisis. Enzim protease yang digunakan semakin meningkat dapat meningkatkan hidrolisa protein-protein daging. Istika (2009) menyatakan protein (kolagen dan miofibril) terhidrolisis menyebabkan hilangnya ikatan antar serat dan pemecahan serat menjadi fragmen yang lebih pendek, menjadikan serat otot lebih mudah terpisah sehingga daging lebih empuk. Ekstrak buah nanas yang ditambahkan semakin banyak, maka jaringan ikat yang terhidrolisis semakin banyak dan daging lebih empuk.

Uji lanjut BNT pada faktor A dan B yang berbeda terhadap susut masak daging kuda menunjukkan tidak berbeda nyata $(p>0,05)$. Dimana faktor A1 tidak berbeda terhadap A2, A2 tidak berbeda terhadap A3. Sedangkan faktor B1 menujukkan tidak berbeda terhadap B2, B2 tidak berbeda terhadap B3. Mgmc (2009) menyatakan bromelin dari ekstrak sari buah nanas memiliki potensi yang sama dengan papain yang ditemukan pada pepaya, sehingga nanas bermanfaat sebagai penghancur lemak. Dimungkinkan semakin banyak konsentrasi ekstrak buah nanas yang ditambahkan lebih banyak lemak yang larut, sehingga akan menurunkan nilai susut masak daging.

\section{2. $\mathrm{pH}$}

Hasil rataan tingkat $\mathrm{pH}$ daging kuda diberi bahan pengempuk alami ekstrak buah nenas (Ananas comosusu l.merr) dapat dilihat pada Tabel 4. 
Tabel 4. Rataan Nilai pH Daging Kuda Berdasarkan Penggaruh Ekstrak Buah Nenas (Ananas comosus l.merr) dengan Lama Perebusan yang berbeda.

\begin{tabular}{|c|c|c|c|c|}
\hline \multirow{2}{*}{$\begin{array}{c}\text { faktor A } \\
\text { (Persentase penambahan } \\
\text { ekstrak sari buah nenas) }\end{array}$} & \multicolumn{3}{|c|}{$\begin{array}{c}\text { Faktor B } \\
\text { (Lama Perebusan yang Berbeda) }\end{array}$} & \multirow[t]{2}{*}{ Rataan } \\
\hline & B1 & B2 & B3 & \\
\hline A1 & $5,34 \pm 0,46$ & $5,15 \pm 0,07$ & $5,54 \pm 0,45$ & $5,35 \pm 0,59$ \\
\hline $\mathrm{A} 2$ & $5,69 \pm 0,19$ & $5,68 \pm 0,23$ & $5,59 \pm 0,19$ & $5,65 \pm 0,16$ \\
\hline A3 & $5,43 \pm 0,19$ & $5,54 \pm 0,36$ & $5,36 \pm 0,30$ & $5,44 \pm 0,28$ \\
\hline Rataan & $5,49 \pm 0,54$ & $5,46 \pm 0,82$ & $5,50 \pm 0,37$ & \\
\hline
\end{tabular}

- $\quad$ ket. superskrip yang berbeda pada kolom dan baris yang sama menunjukan berbeda nyata $(p>0,05)$

Interaksi antara faktor $\mathrm{A}$ dan $\mathrm{B}$ tidak berpengaruh nyata $(p>0,05)$ terhadap $\mathrm{pH}$ daging. Berdasarkan uji sidik ragam antara faktor A dan faktor B secara tunggal tidak berpengaruh nyata $(p>0,05)$. Hasil penelitian terhadap $\mathrm{pH}$ daging kuda dalam kisaran $\mathrm{pH}$ normal daging. Hal ini sejalan dengan pernyataan Seoparno (2009) bahwa $\mathrm{pH}$ daging akan mengalami perubahan (penurunan) sesuai dengan waktu penyimpanan, semakin lama penyimpanan $\mathrm{pH}$ akan semakin menurun sampai tercapai $\mathrm{pH}$ akhir yaitu antara 5,4 - 5,8. Hasil penelitian menunjukkan semakin lama waktu pemasakan akan meningkatkan $\mathrm{pH}$ daging. Menurut hasil penelitian Ridwan (2004) lama pemasakan memberikan pengaruh nyata terhadap $\mathrm{pH}$ daging.

\section{B. Kualitas Organoleptik Daging Kuda}

Uji organoleptik pada daging kuda menggunakan skala hedonik yang bertujuan menentukan tingkat kesukaan panelis dengan kriteria mutu yang ditetapkan yaitu Keempukan, rasa, aroma, tekstur dan sari minyak (Juiceness) Skala hedonik yaitu (1) sangat disuka, (2) suka, (3) cukup disuka, (4) kurang suka (5) tidak disukai. Sedangkan skala hedonik warna tidak di uji. Rataan interaksi skor penilaian panelis terhadap kualitas organoleptik kuda.

\section{Keempukan}

Rataan tingkat keempukan daging kuda diberi bahan pengempuk alami ekstrak buah nenas (Ananas comosusu l.merr) dapat dilihat pada Tabel 5.

Tabel 5. Rataan Nilai Skor Keempukkan Daging Kuda Berdasarkan Penggaruh Eksrak Buah Nenas (Ananas comosus l.merr) dengan Lama Perebusan yang berbeda.

\begin{tabular}{ccccc}
\hline $\begin{array}{c}\text { Faktor A } \\
\text { (Persentase penambahan } \\
\text { ekstrak buah nenas) }\end{array}$ & \multicolumn{3}{c}{ Faktor B } & Rataan \\
\cline { 2 - 4 } & B1 & B2 & B3 & \\
\hline A1 & $3,00 \pm 0,06$ & $3,13 \pm 0,10$ & $2,73 \pm 0,28$ & $2,96^{\mathrm{a}} \pm 0,65$ \\
A2 & $2,23 \pm 0,05$ & $2,40 \pm 0,06$ & $2,08 \pm 0,10$ & $2,24^{\mathrm{b}} \pm 0,66$ \\
A3 & $2,02 \pm 0,13$ & $2,07 \pm 0,23$ & $1,93 \pm 0,15$ & $2,01^{\mathrm{c}} \pm 0,54$ \\
\hline Rataan & $2,42^{\mathrm{a}} \pm 1,56$ & $2,53^{\mathrm{a}} \pm 1,99$ & $2,25^{\mathrm{b}} \pm 1,65$ & \\
\hline
\end{tabular}

- $\quad$ Ket. Superskrip yang berbeda pada kolom dan baris yang sama menunjukkan perbeda yang nyata $(p<0,05)$

Interaksi antara faktor A dan faktor B tidak menunjukkan pengaruh nyata $(p>0,05)$ terhadap nilai keempukan daging kuda. Menurut Fisher (2009) faktor yang sangat berpengaruh terhadap kecepatan hidrolisis yaitu konsentrasi enzim yang ditambahkan, waktu hidrolisis (inkubasi), dan suhu. Astutiamin's (2009) menyatakan pertambahan konsentrasi enzim akan menaikkan kecepatan reaksi (hidrolisis jaringan ikat), pada batas konsentrasi tertentu tidak terjadi kenaikan jumlah jaringan ikat yang terhidrolisis walaupun konsentrasi enzim diperbesar. 
Hasil uji sidik ragam faktor A secara tunggal berpengaruh sangat nyata terhadap skor nilai keempukan $(p<0,01)$ dimana A3 lebih baik dibandingkan dengan A2 dan A1. Hasil ini menunjukkan dengan meningkatnya konsentrasi ekstrak buah nenas terjadi penurunan nilai daya tusuk daging.

Konsentrasi ekstrak buah nenas 5\% memberikan peningkatan keempukan daging. Diduga pada konsentrasi ekstrak buah nenas 5\% sudah terjadi hidrolisis jaringan ikat, sesuai dengan penelitian Murtini dan Qomarudin (2003) penambahan enzim protease dari tanaman nenas pada konsentrasi 5\% sudah cukup memberikan peningkatan keempukan dibanding kontrol. Menurut Lee et al., (1994) enzim protease berfungsi mengempukkan daging, karena protein pada jaringan ikat dan fragmentasi miofibril dengan degradasi pada filamenfilamen akan terhidrolisis. Enzim protease yang digunakan semakin meningkat dapat meningkatkan hidrolisa protein-protein daging. Istika (2009) menyatakan protein (kolagen dan miofibril) terhidrolisis menyebabkan hilangnya ikatan antar serat dan pemecahan serat menjadi fragmen yang lebih pendek,serat otot lebih mudah terpisah sehingga daging lebih empuk.

Sedangkan faktor B secara tunggal berpengaruh nyata $(p<0,05)$ terhadap perebusan A1, A2, A3 terhadap nilai keempukan daging dimana skor A3 $(2,25)$ lebih baik dibandingkan A2(2,53) dan A1 $(2,42)$. Hasil penelitian menunjukkan bahwa pada perebusan selama 50 menit akan menunjukkan nilai daya tusuk daging menurun, ini sesuai dengan penelitian Sudrajat (2003), menyatakan bahwa lama pemasakan memberikan perbedaan yang nyata terhadap keempukan daging, yang ditunjukkan dengan lama perebusan meningkat daging semakin empuk. Semakin lama pemasakan ikatan serabut otot semakin melonggar sehingga daging menjadi lebih empuk.

Hasil uji lanjut BNT pada faktor A dan faktor $B$ menunjukkan tidak berpengaruh nyata terhadap keempukan daging kuda. Berdasarkan hasil penelitian ini daging kuda adalah empuk dengan skor dua (2). Dimana nilai keempukkan terhadap penambahan ekstrak sari buah nenas $10 \%$ lebih baik. Pada penelitian ini untuk memperoleh hasil yang baik dalam memanfaatkan enzim bromelin yang dapat membantu proses pengempukan yaitu pada kisaran suhu perebusan $60^{\circ} \mathrm{C}$. Hal tersebut sesuai pendapat Menurut Widodo (2010) panas diperlukan bahan makanan menjadi matang. Pada saat bagian dalam daging mencapai suhu $60^{\circ} \mathrm{C}$ akan terjadi perubahan jaringan ikat elastin akan mengkerut sehingga cairan dalam daging akan keluar. Menurut hasil penelitian Nurhasanah dan Herasari (2008) suhu yang lebih rendah dari suhu optimum, aktivitas enzim juga rendah dan sebaliknya.

\section{Rasa}

Hasil rataan tingkat rasa daging kuda diberi bahan pengempuk alami ekstrak buah nenas (Ananas comosusu l.merr) dapat dilihat pada Tabel 6.

Tabel 6. Rataan Nilai Skor Rasa Daging Kuda Berdasarkan Penggaruh Ekstrak Buah Nenas (Ananas comosus l.merr) dengan Lama Perebusan yang berbeda.

\begin{tabular}{|c|c|c|c|c|}
\hline \multirow{2}{*}{$\begin{array}{c}\text { faktor A } \\
\text { (Persentase penambahan ekstrak } \\
\text { buah nenas) }\end{array}$} & \multicolumn{3}{|c|}{$\begin{array}{c}\text { Faktor B } \\
\text { (Lama Perebusan yang Berbeda) }\end{array}$} & \multirow[t]{2}{*}{ Rataan } \\
\hline & B1 & B2 & B3 & \\
\hline A1 & $3,05^{\mathrm{ab}} \pm 0,05$ & $2,80^{\mathrm{ab}} \pm 0,10$ & $2,60^{\mathrm{b}} \pm 0,17$ & $2,82^{\mathrm{a}} \pm 0,68$ \\
\hline $\mathrm{A} 2$ & $2,78^{\mathrm{ab}} \pm 0,10$ & $2,82^{\mathrm{ab}} \pm 0,24$ & $2,75^{\mathrm{ab}} \pm 0,31$ & $2,78^{\mathrm{a}} \pm 0,10$ \\
\hline A3 & $3,00^{\mathrm{ab}} \pm 0,05$ & $2,90^{\mathrm{ab}} \pm 0,10$ & $3,15^{\mathrm{a}} \pm 0,13$ & $3,02^{\mathrm{b}} \pm 0,38$ \\
\hline Rataan & $2,94 \pm 0,43$ & $2,84 \pm 0,16$ & $2,83 \pm 0,85$ & \\
\hline
\end{tabular}

- $\quad$ Ket. Superskrip yang berbeda pada kolom dan baris yang sama menunjukkan perbedaan yang nyata $(p<0,05)$ 
Interaksi antara faktor A dan B berpengaruh nyata $(p<0,05)$ terhadap nilai skor rasa organoleptik daging kuda. Hasil penelitian ini terhadap rasa daging kuda cukup disukai dengan skor tiga (3). Hal ini menunjukkan bahwa konsentrasi sari nenas dan lama perebusan meningkatkan rasa daging, tetapi pada konsentrasi dan perebusan yang berlebih justru menurunkan rasa daging.

Hasil analisis ragam pada faktor A berpengaruh Nyata $(p<0,05)$ nilai A2 $(2,78)$ dengan penambahan ekstrak sari buah nenas 5\% jauh lebih baik dibandingkan A1 $(2,82)$. A1 $(2,82)$ lebih baik dibandingkan A3 $(3,02)$ terhadap nilai organoleptik rasa daging kuda. Berbeda halnya dengan faktor B tidak berpengaruh nyata $(p>0,05)$ pada B3 $(2,83)$ dengan lama perebusan 50 menit lebih baik dibandingkan B2 $(2,84)$. B2 $(2,84)$ lebih baik dibandingkan B1 $(2,94)$. Hasil uji lanjut BNT menunjukkan adanya interaksi antara A persentase penambahan ekstrak sari buah nenas dan B lama perebusan yang berbeda. Faktor A1B1 $(3,05)$ berbeda nyata terhadap A1B2 $(2,80)$, A1B2 $(2,80)$ berbeda nyata A1B3 $(2,60)$. A2B1 $(2,78)$ tidak berbeda nyata terhadap A2B2 $(2,82)$, A2B2 $(2,82)$ berbeda nyata pada A2B3 $(2,75)$. Sedangkan A3B1 $(3,00)$ berbeda nyata terhadap A3B2 (2,90). A3B1 $(3,00)$ tidak berbeda nyata pada A3B3 $(3,15)$. Interaksi perlakuan yang terbaik adalah A1B3 $(2,60)$ dimana A1 tanpa penambahan ekstrak sari buah nenas dan B3 lama perebusan 50 menit.

\section{Aroma}

Hasil rataan tingkat aroma daging kuda diberi bahan pengempuk alami ekstrak buah nenas (Ananas comosusu l.merr) dapat dilihat pada Tabel 7.

Tabel 7. Rataan Nilai Skor Aroma Daging Kuda Berdasarkan Penggaruh Ekstrak Buah Nenas (Ananas comosus l.merr) dengan Lama Perebusan yang berbeda.

\begin{tabular}{ccccc}
\hline \multirow{2}{*}{$\begin{array}{c}\text { faktor A } \\
\text { Persentase penambahan ekstrak } \\
\text { buah nenas) }\end{array}$} & \multicolumn{3}{c}{ Faktor B } & Rataan \\
\cline { 2 - 4 } & \multicolumn{1}{c}{ B1 } & B2 & B3 & \\
\hline A1 & $2,38^{\mathrm{a}} \pm 0,06$ & $2,62^{\mathrm{bc}} \pm 0,10$ & $2,70^{\mathrm{bc}} \pm 0,25$ & $2,57 \pm 0,49$ \\
A2 & $2,63^{\mathrm{bc}} \pm 0,18$ & $2,52^{\mathrm{ab}} \pm 0,26$ & $2,42^{\mathrm{ab}} \pm 0,13$ & $2,52 \pm 0,33$ \\
A3 & $2,67^{\mathrm{bc}} \pm 0,03$ & $2,78^{\mathrm{bc}} \pm 0,15$ & $2,47^{\mathrm{ab}} \pm 0,10$ & $2,64 \pm 0,48$ \\
\hline Rataan & $2,56 \pm 0,46$ & $2,64 \pm 0,40$ & $2,53 \pm 0,45$ & \\
\hline
\end{tabular}

Ket. Superskrip yang berbeda pada kolom dan baris yang sama menunjukkan perbedaan yang nyata $(p<0,05)$

Hasil analisis secara mandiri faktor A dan faktor B tidak berpengaruh nyata $(p>0,05)$ terhadap aroma daging kuda.

Interaksi antara faktor A dan faktor B berpengaruh nyata $(p<0,05)$ terhadap aroma daging kuda. Dari hasil penelitian daging kuda ini disukai dengan skor dua (2). Hal ini diduga semakin lama waktu penambahan ekstrak sari buah nenas akan meningkatkan nilai penerimaan terhadap aroma daging. semakin lama waktu perendaman, maka sari nenas lebih meresap ke dalam serabut otot, yang menyebabkan aroma harum nenas lebih menonjol pada saat daging dimasak. Menurut soeparno
(2009), aroma dan rasa daging masak banyak ditentukan oleh precursor yang larut dalam air dan lemak dan pembebasan senyawa atsiri (Volatil) yang terdapat dalam daging.

Uji lanjut BNT menunjukkan ada interaksi antara penambahan ekstrak sari buah nenas $(0,5$ dan 10 persen) dan lama perebusan (30, 40 dan 50 menit) berpengaruh nyata $(p<0,05)$ terhadap daging kuda. Interaksi dengan perlakuan terbaik adalah A2 penambahan 5\% ekstrak sari buah nenas dengan B3 lama perebusan selama 50 menit dengan nilai skor 2,42 (disukai). 


\section{Tekstur}

Hasil rataan tingkat tekstur daging kuda diberi bahan pengempuk alami ekstrak buah nenas (Ananas comosusu l.merr) dapat dilihat pada Tabel 8.

Tabel 8. Rataan Nilai Skor Tekstur Daging Kuda Berdasarkan Penggaruh Ekstrak Buah Nenas (Ananas comosus l.merr) dengan Lama Perebusan yang berbeda.

\begin{tabular}{ccccc}
\hline $\begin{array}{c}\text { faktor A } \\
\text { Persentase penambahan } \\
\text { ekstrak buah nenas) }\end{array}$ & \multicolumn{3}{c}{ Faktor B } & Rataan \\
\cline { 2 - 4 } & B1 & B2 & B3 Perebusan yang Berbeda) & \\
\hline A1 & $2,63 \pm 0,15$ & $2,92 \pm 0,23$ & $2,52 \pm 0,15$ & $2,69^{\text {a }} \pm 0,62$ \\
A2 & $2,32 \pm 0,19$ & $2,15 \pm 0,17$ & $2,28 \pm 0,13$ & $2,25^{\mathrm{b}} \pm 0,26$ \\
A3 & $2,25 \pm 0,36$ & $1,87 \pm 0,19$ & $2,00 \pm 0,23$ & $2,04^{\mathrm{c}} \pm 0,58$ \\
\hline Rataan & $2,40 \pm 0,61$ & $2,31 \pm 1,63$ & $2,27 \pm 0,78$ & \\
\hline
\end{tabular}

- $\quad$ Ket. Superskrip yang berbeda pada kolom dan baris yang sama menunjukkan perbedaan yang nyata $(p<0,05)$

Interaksi antara faktor A dan faktor B tidak berpengaruh nyata $(p>0,05)$ terhadap nilai skor tekstur daging kuda. Hasil uji penelitian ini menunjukkan bahwa daging kuda adalah empuk dengan skor dua(2). Hal tersebut dikarenakan adanya penambahan ekstrak sari buah nenas dengan persentase yang berbeda dengan lama perebusan. Hasil penelitian ini sesuai dengan pendapat Radiati (2014) bahwa larutan ekstrak nanas dengan penambahan konsentrasi dan lama waktu perendaman berbeda pada daging akan semakin empuk. Menurut Richardson dan Mead (1999) faktor utama yang menentukan keempukan daging adalah tingkat kontraksi otot yang tidak tetap ada permulaan rigor yang dapat disebabkan oleh beberapa sifat psikologis dan prosedur pengolahan.

Berdasarkan uji sidik ragam terhadap tekstur daging kuda pada faktor A berpengaruh sangat nyata $(p<0,01)$ terhadap tekstur daging kuda, dimana A3 $(2,04)$ lebih baik dibandingkan dengan A2 $(2,25)$ dan $\mathrm{A} 1(2,69)$, sedangkan pada faktor B tidak berbeda nyata $(p>0,05)$ pada tekstur daging kuda. Hasil Uji lanjut BNT terhadap faktor A berpengaruh nyata $(p<0,05)$ dimana A1B1 $(2,38)$ berbeda terhadap A1B2 dan A1B3. A1B2 berbeda terhadap A1B3. A2B1 berbeda terhadap A2B2. A2B2 berbeda terhadap A2B3. Sedangkan A3B1 tidak berbeda terhadap A3B2. A3B2 berbeda terhadap A3B3. Interaksi antar perlakuan terbaik adalah A2B3 dimana A2 persentase penambahan ekstrak buah nenas 5\% dan B3 lama perebusan 50 menit.

5. Sari minyak (Juiceness)

Hasil rataan tingkat Sari minyak (Juiceness) daging kuda diberi bahan pengempuk alami ekstrak buah nenas (Ananas comosusu l.merr) dapat dilihat pada Tabel 9

Tabel 9. Rataan Nilai Skor Minyak (Juiceness) Daging Kuda Berdasarkan Pengaruh Ekstrak Sari Buah Nenas (Ananas comosus l.merr) dengan Lama Perebusan yang berbeda.

\begin{tabular}{ccccc}
\hline \multirow{2}{*}{$\begin{array}{c}\text { faktor A } \\
\text { (Persentase penambahan ekstrak } \\
\text { buah nenas) }\end{array}$} & B1 & B2 & Rataan \\
\cline { 2 - 4 } A1 & $3,38 \pm 0,09$ & $3,48 \pm 0,25$ & $3,07 \pm 0,44$ & $3,31^{\text {a }} \pm 0,61$ \\
A2 & $2,60 \pm 0,25$ & $2,32 \pm 0,25$ & $2,17 \pm 0,42$ & $2,36^{\mathrm{a}} \pm 0,48$ \\
A3 & $2,40 \pm 0,10$ & $2,35 \pm 0,23$ & $2,07 \pm 0,03$ & $2,27^{\mathrm{b}} \pm 0,20$ \\
\hline Rataan & $2,79^{\mathrm{a}} \pm 1,55$ & $2,72^{\mathrm{a}} \pm 1,64$ & $2,43^{\mathrm{b}} \pm 1,28$ & \\
\hline
\end{tabular}

- $\quad$ Ket. Superskrip yang berbeda pada kolom dan baris yang sama menunjukkan perbedaan yang nyata $(p<0,05)$ 
Interaksi antara penambahan ekstrak buah nanas dengan lama perebusan tidak menunjukkan pengaruh nyata ( $p>0,05)$ terhadap sari minyak (juiceness) daging kuda. Berdasarkan hasil uji analisis ragam pada faktor $\mathrm{A}$ dan $\mathrm{B}$ berpengaruh sangat nyata $(p<0,01)$ terhadap skor sari minyak daging kuda. Hasil penelitian ini menunjukkan bahwa daging kuda dengan penambahan ekstrak sari buah nenas dan lama perebusan yang berbeda menghasilkan kesan berminyak (juicy) dengan skor dua (2) terhadap daging kuda. Juiciness atau kesan juicy produk daging dipengaruhi oleh jumlah air yang dapat dipertahankan untuk tetap berada di dalam daging setelah dimasak dan produksi saliva (air ludah) pada saat pengunyahan.

Uji lanjut BNT terhadap interaksi antara faktor A menunjukan tidak berbeda nyata $(p>0,05)$ dimana A3 tidak berpengaruh dengan A1. A1 tidak berbeda dengan A2. Sedangkan faktor B menunjukkan tidak berbeda nyata $(p>0,05)$. Dimana B3 sama tidak berbeda dengan B2 begitu pula terhadap B1. Daging kuda umumnya memiliki kandungan minyak yang banyak, namun rendah kolesterol. Hal tersebut sesuai pendapat Soeparno (2009) daging yang berkualitas baik secara relatif mengandung lebih banyak jus dari pada daging berkualitas rendah. Sebagian dari perbedaan kualitas ini antara lain adalah karena daging yang berkualitas baik relative lebih banyak mengandung lemak intramuskular.

\section{KESIMPULAN}

Berdasarkan hasil dan pembahasan dapat disimpulkan sebagai berikut:

1. Interaksi antara penambahan ekstrak buah nenas dan waktu pemasakan tidak berpengaruh nyata terhadap kualitas organoleptik (keempukan, tekstur, juiceness) dan kualitas fisik (susut masak, pH) akan tetapi berpengaruh nyata terhadap rasa dan aroma daging kuda.

2. Ekstrak buah nenas secara mandiri berpengaruh nyata terhadap kualitas fisik susut masak dan kualitas organoleptik berupa keempukan, rasa, tekstur, juiceness daging kuda.

3. Waktu lama perebusan, berpengaruh nyata terhadap keempukan, juiceness dan susut masak daging kuda.

\section{DAFTAR PUSTAKA}

Astuiamin's. 2009. Enzim dan Koenzim. W ebsite: http://astutiamin.wordpress.c om/. Diakses: Tanggal 01 Juni 2010.

Fisher, N. 2009. Hidrosilat Protein Ikan. Wab-site: http://naKEd_fiSHer.archive.com. Diakses: Tanggal 01 Juni 2010.

Gaspersz, 1989. Metode Perancangan Percobaan. Armico. Bandung

Hafid, H., dan Syam, A. 2007. Pengaruh aging dan lokasi otot terhadap kualitas organoleptik daging sapi. Buletin Peternakan. 3 (4) : 209 216.

Hafid, H. 2008. Strategi Pengembangan Peternakan Sapi Potong di Sulaesi Tenggara Dalam Mendukung Pencapaian Swasembada Daging Nasional : Orasi Ilmiah Pengukuhan Guru Besar. Universitas Haluoleo. Kendari

Hafid, H., dan Syam, A. 2009. Organoleptik daging kambing lokal dengan lama pelayuan dan cara pemasakan yang berbeda. Jurnal Penelitian Agroland, Universitas Tadulaku, Palu.

Hafid, H. 2011. Pengantar Evaluasi Karkas. Cetakan Pertama. Penerbit Unhalu Press, Kendari.

Hafid, H., Nuraini dan Inderawati. 2013. Pengaruh ekstrak buah nenas muda terhadap kualitas sensori daging 
kerbau. Majalah Ilmiah Agriplus. 23 (1) : $18-23$.

Hanafiah, K. 2004. Rancangan Percobaan Teori dan Aplikasi. Raja Grafindo Persada. Jakarta.

Istika, D. 2009. Pemanfaatan enzim bromelain pada limbah kulit nanas (Ananas comosus (L.) merr) dalam pengempukan daging. Jurusan Biologi. Fakultas Matematika dan Ilmu Lingkungan pengetahuan Alam. Universitas Sebelas Maret. Surakarta.

Lawrie, R. A. 2003. Meat science. Edisi Ke-5. Penerjemah: A. Perakasi. UI press. Jakarta.

Lee, Y. B., Sehnert, D. J., and Ashmore, C. R. 1994. tenderization of meat with ginger rhizome. J. Food Sci.. 51 (16): 1558-1559.

Mgmc. 2009. Nanas. Web-site: http://miskal-mgmc.blogspot.com/. Diakses: Tanggal 07 April 2010.

Murtini, E.S., dan Qomarudin. 2003. Pengempukan daging dengan enzim protease tanaman nenas (Calotropis gigantea). J. Tek. dan Industri Pangan. XIV (3): 266-268.

Nurhasanah dan Herasari, D. 2008. Pemurnian enzim lipase dari bakteri lokal dan aplikasinya dalam reaksi esterifikasi. Prosiding: Seminar Nasional Sains dan Teknologi. Universitas Lampung. Lampung.

Radiati L. E. (2014) Pengaruh penambahan larutan ekstrak nanas dan perendaman terhadap kualitas fisik dan organoleptik daging ayam kampong segar bagian dada. Program Studi Ilmu Peternakan Fakultas Peternakan Universitas Brawijaya. Malang
Richardson, R.I., and Mead, G.C. 1999.Poultry meat science.Poultry Science Symposium Series. Volume Twenty Five.CABI Publishing. London.

Ridwan. A. 2004. Pengaruh cara dan waktu pemasakan yang berbeda terhadap kualitas fisik daging itik afkir yang dipelihara secara kering. Skripsi. Jurusan Produksi Ternak. Fakultas Pertanian. Universitas Sebelas Maret. Surakarta.

Soeparno. 2009. Ilmu dan Teknologi Daging. Cetakan ke lima. Gadjah Mada University Press. Yogyakarta.

Sudrajat, A. 2003. Pengaruh temperatur dan lama pemasakan terhadap karakteristik fisik dan organoleptik daging ayam broiler. Skripsi. Fakultas Peternakan, Universitas Gadjah Mada. Yogyakarta.

Widodo, W. 2010. Mengungkep. Website: www.wordpress.com. Diakses: Tanggal 05 Mei 2010.

Winarno, F. G., S. Fardiaz dan D. Fardiaz. 1993. Pengantar Teknologi Pangan. PT. Gramedia Pustaka Utama. Jakarta. 